\title{
Pengaruh Pemberian Kalsium Terhadap Tekanan Darah Pada Ibu Hamil Dengan Hipertensi
}

\author{
Eline Charla Sabatina Bingan \\ Prodi D.IV Kebidanan, Jurusan Kebidanan Poltekkes Kemenkes Palangka Raya; \\ Jalan George Obos No. 30/ 32, Palangka Raya 73111 \\ Telp/Fax : (0536) 3221768, 3230730 \\ e-mail:elinbingan@yahoo.com, elinecarlabingan@gmail.com
}

Naskah Diterima : 02 Oktober 2018 Disetujui : 10 Desember 2018 Publikasi : Januari 2019

\begin{abstract}
ABSTRAK
Latar Belakang: Salah satu keadaan patologis yang sering terjadi pada ibu adalah Hipertensi Dalam Kehamilan (HDK), yang berakibat fatal apabila tidak terdeteksi secara dini sehingga mengarah kepada preeklamsia. Berbagai uji klinis dilaporkan kejadian hipertensi hingga preeklampsia menjadi berkurang dengan pemberian suplementasi kalsium, tekanan darah menjadi rendah, dengan pemberian kalsium.

Tujuan: Mengetahui Pengaruh Pemberian Kalsium terhadap Tekanan Darah pada Ibu Hamil dengan Hipertensi.

Metode Penelitian: Penelitian ini menggunakan desain Quasy Eksperimen. Pengumpulan data dilakukan dengan observasi mengikuti proses pemeriksaan kehamilan pada ibu hamil dengan hipertensi. Perlakuan dengan pemberian susu berkomposisi kalsium 40\% kemudian diobservasi tekanan darah selama 3 hari. Penelitian ini dilakukan di Wilayah Kerja Puskesmas Panarung Kota Palangka Raya Provinsi Kalimantan Tengah dari tanggal 1 Maret 2018 sampai dengan 25 Mei 2018. Besar sampel dalam penelitian ini 26 responden. Uji statistik dengan menggunakan Chi-Square.

Hasil: Berdasarkan uji statistik menunjukkan bahwa nilai Sig.(2-tailed) 0,000 $<0,05$ maka ada hubungan antara pemberian kalsium dengan tekanan darah pada ibu hamil dengan hipertensi.

Kesimpulan: Pemberian kalsium, usia dan riwayat keturunan secara statistik terbukti berhubungan dengan tekanan darah pada ibu hamil, rekomendasi kalsium sebagai salah satu alternatif dalam mengatasi tekanan ibu hamil.
\end{abstract}

Kata Kunci: Hipertensi, Kalsium, Tekanan Darah.

\section{PENDAHULUAN}

Salah satu keadaan patologis yang sering terjadi pada ibu adalah Hipertensi Dalam Kehamilan (HDK). Hipertensi Dalam Kehamilan (HDK) dapat berakibat fatal apabila tidak terdeteksi secara dini dan dapat mengarah kepada preeklamsi. Di masa yang akan datang besar kemungkinan Angka Kematian Ibu (AKI) dan Angka Kematian Bayi (AKB) disebabkan oleh hipertensi. (1)

Saat ini hipertensi merupakan masalah kedokteran yang serius dan memiliki tingkat kompleksitas yang tinggi. Besarnya masalah ini bukan hanya karena hipertensi berdampak pada ibu saat hamil dan melahirkan, namun pasca persalinan dapat menimbulkan disfungsi pada berbagai organ seperti risiko penyakit kardiometabolik dan komplikasi lainnya.

Adapun rincian penyebab langsung kematian ibu di Provinsi Kalimantan Tengah Tahun 2016 sebagai berikut: perdarahan 73 kasus, Hipertensi Dalam Kehamilan 13 Kasus, Gangguan sistem pembuluh darah 11 kasus dan lain-lain 12 kasus. (2) Beberapa metode dan obat-obatan telah dilakukan penelitian untuk upaya pencegahan dan deteksi dini hipertensi. Upaya pencegahan yang telah diteliti adalah pemberian asam asetil salisilat dosis rendah, kalsium, antioksidan termasuk vitamin $\mathrm{C}$ dan $\mathrm{E}$, serta fortifikasi (pemberian suplemen 
makanan) L-arginine. Beberapa penelitian pemberian antioksidan berupa multivitamin pada berbagai etnis menunjukkan secara signifikan tidak bermanfat mencegah hipertensi. (3)

Berbagai uji klinis dilaporkan kurangnya kejadian hipertensi hingga pre eklamsi dengan suplementasi kalsium, yang lain melaporkan asosiasi tekanan darah rendah, dengan kalsium makanan yang lebih tinggi. Studi epidemiologi telah mengungkapkan hubungan antara asupan kalsium selama kehamilan.

Berdasarkan uraian di atas, maka peneliti merasa tertarik untuk melakukan penelitian tentang Pengaruh Pemberian Kalsium Terhadap Tekanan Darah Pada Ibu Hamil Dengan Hipertensi di Wilayah Kerja Puskesmas Panarung Kota Palangka Raya Tahun 2018.

\section{METODE}

Jenis penelitian yang digunakan adalah observasional analitik dengan rancangan Cross Sectional . Pemilihan lokasi penelitian dilakukan secara Probability, yaitu di Puskesmas Panarung Kota Palangka Raya. Penelitian ini dilaksanakan pada bulan Maret sampai bulan Mei 2018. Populasi adalah seluruh ibu hamil yang menderita Hipertensi di wilayah kerja Puskesmas Panarung Kota Palangka Raya. Kriteria inklusi yang ditetapkan adalah ibu hamil yang didiagnosis hipertensi yang bersedia diberikan Susu Prenagen dengan komposisi Kalsium 40\%. Jumlah subjek minimal, menggunakan rumus Lameshow et al. adalah 26 responden. Setelah proses pengumpulan data selesai, didapatkan subjek ibu hamil yang mengikuti penelitian dengan data yang lengkap berjumlah 26 orang. Susu Kalsium diberikan saat Kunjungan ANC ibu hamil. Variabel terikat yaitu pemberian Kalsium, sedangkan variabel bebas yaitu tekanan darah. Wawancara terstruktur menggunakan Kuesioner untuk mengetahui data Ibu Hamil yang meliputi Usia, Paritas, dan Riwayat Keturunan. Tingkat kecukupan Kalsium pada penelitian ini didapatkan dari rata-rata asupan Kalsium mengkonsumsi Susu Hamil dengan Kandungan Kalsium 40\% setelah itu dilakukan pengukuran Tekanan Darah pada Ibu Hamil. Adapun penelitian ini sudah melalui komisi Etik Poltekkes Kemenkes Palangka Raya.

\section{HASIL}

Hasil penelitian ini disajikan dalam bentuk tabel. Pada hasil penelitian diuraikan tentang variabel dependent dan variabel independent. Variabel dependen meliputi pengaruh pemberian kalsium dan variabel independent yaitu tekanan darah pada ibu hamil dengan hipertensi. Variabel pengganggu meliputi tekanan darah, usia, paritas, riwayat keturunan.

\section{Analisis Univariat}

Tabel 1 Distribusi Frekuensi Pengaruh Pemberian Kalsium Terhadap Tekanan Darah Pada Ibu Hamil Dengan Hipertensi

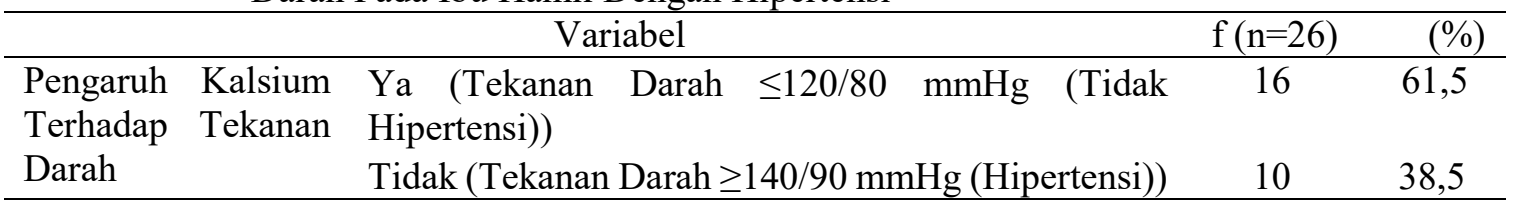

Tabel 1 Menunjukkan bahwa sebagian besar kalsium berpengaruh terhadap tekanan darah
$(61,5 \%)$ responden dan tidak berpengaruh terhadap tekanan darah $(38,5 \%)$ 
Tabel 2 Distribusi Frekuensi berdasarkan Usia, Paritas dan Riwayat Keturunan

\begin{tabular}{lcc}
\hline \multicolumn{1}{c}{ Variabel } & $\mathrm{f}$ & $(\%)$ \\
\hline Usia : & & \\
20 - 35 Tahun & 13 & 50 \\
>35 Tahun & 13 & 50 \\
\hline Paritas : & & \\
Primipara & 6 & 23,1 \\
Multipara & 12 & 46,2 \\
$\quad$ Grandemultipara & 8 & 30,8 \\
\hline Riwayat Keturunan : & & \\
Ada & 16 & 61,5 \\
Tidak ada & 10 & 38,5 \\
\hline
\end{tabular}

Tabel 2 Menunjukkan distribusi frekuensi reponden dengan kategori usia 20 - 35 tahun dan usia $>35$ tahun sama banyaknya. berdasarkan paritas terbanyak adalah responden dengan multipara, sementara menurut riawayat keturunan menunjukkan jumlah terbanyak $(61,5 \%)$ dibanding dengan tidak ada riwayat keturunan $(38,5 \%)$.

2. Analisis Bivariat

Tabel 3 Pengaruh Pemberian Kalsium Terhadap Tekanan Darah Pada Ibu Hamil Dengan Hipertensi

\begin{tabular}{lccc}
\hline Variabel & $\mathrm{n}$ & $\%$ & $\mathrm{p}$ \\
\hline Tekanan Darah $\leq 120 / 80 \mathrm{mmHg}$ (Tidak Hipertensi) & 16 & 61,5 & 0,001 \\
\hline Tekanan Darah $\geq 140 / 90 \mathrm{mmHg}$ (Hipertensi) & 10 & 38,5 & \\
\hline
\end{tabular}

Tabel 3 Menunjukkan tekanan darah tidak hipertensi sebanyak 16 orang $(61,5 \%)$. Uji statistik menggunakan Chi-Square diperoleh nilai p-value 0.001 , artinya ada hubungan antara pemberian kalsium dengan tekanan darah pada ibu hamil dengan hipertensi.

Tabel 4 Pengaruh Usia dengan Pemberian Kalsium Terhadap Tekanan Darah Pada Ibu Hamil Dengan Hipertensi

\begin{tabular}{lccccc}
\hline \multirow{2}{*}{ Variabel } & \multicolumn{4}{c}{ Usia } & \multirow{2}{*}{$\mathrm{p}$} \\
\cline { 2 - 5 } & $20-35 \mathrm{Th}$ & \multicolumn{2}{c}{$>35 \mathrm{Th}$} & \\
\cline { 2 - 5 } & $\mathrm{n}$ & $\%$ & $\mathrm{n}$ & $\%$ & \\
\hline Tekanan Darah $\leq 120 / 80 \mathrm{mmHg}$ (Tidak Hipertensi) & 13 & 50 & 13 & 50 & 0,023 \\
\hline Tekanan Darah $\geq 140 / 90 \mathrm{mmHg}$ (Hipertensi) & 13 & 50 & 13 & 50 & \\
\hline
\end{tabular}

Tabel 4 Menunjukkan nilai yang sama pada usia 20 - 35 tahun dan $>35$ tahun masing masing sebanyak 13 orang (50\%). Pada bagian Pearson Chi-Square terlihat nilai $\mathrm{p}=$ 0,023 . Dimana nilai $p=0,023<0,05$, maka
Ho ditolak yaitu ada hubungan antara pemberian kalsium dengan tekanan darah pada ibu hamil dengan hipertensi berdasarkan usia. 
Tabel 5 Pengaruh Paritas dengan Pemberian Kalsium Terhadap Tekanan Darah Pada Ibu Hamil Dengan Hipertensi

\begin{tabular}{|c|c|c|c|c|c|c|c|c|}
\hline & \multirow{3}{*}{ Variabel } & \multicolumn{6}{|c|}{ Paritas } & \multirow{3}{*}{$\mathrm{p}$} \\
\hline & & \multicolumn{2}{|c|}{ Primipara } & \multicolumn{2}{|c|}{$\begin{array}{c}\text { Multi } \\
\text { para }\end{array}$} & \multicolumn{2}{|c|}{$\begin{array}{l}\text { Grand- } \\
\text { multipara }\end{array}$} & \\
\hline & & $\mathrm{n}$ & $\%$ & $\mathrm{n}$ & $\%$ & $\mathrm{n}$ & $\%$ & \\
\hline $\begin{array}{l}\text { Tekanan Darah } \\
\text { Hipertensi) }\end{array}$ & $\leq 120 / 80 \quad \mathrm{mmHg} \quad$ (Tidak & 4 & 25 & 7 & 43,8 & 5 & 31,2 & 0,941 \\
\hline Tekanan Darah $\geq$ & 40/90 mmHg (Hipertensi) & 2 & 20 & 5 & 50 & 3 & 30 & \\
\hline
\end{tabular}

Tabel 5 Menunjukkan nilai yang paling tinggi terdapat pada multipara sebanyak 12 orang $(46,2 \%)$. Pada bagian Pearson ChiSquare terlihat nilai $\mathrm{p}=0,941$. Dimana nilai $\mathrm{p}=0,941>0,05$, maka artinya tidak ada hubungan antara pemberian kalsium dengan tekanan darah pada ibu hamil dengan hipertensi berdasarkan paritas.

Tabel 6 Pengaruh Riwayat Keturunan dengan Pemberian Kalsium Terhadap Tekanan Darah Pada Ibu Hamil Dengan Hipertensi

\begin{tabular}{lcccccc}
\hline \multirow{2}{*}{ Variabel } & \multicolumn{4}{c}{ Riwayat Keturunan } & \multirow{2}{*}{ P } \\
\cline { 2 - 5 } & $\mathrm{n}$ & $\%$ & $\mathrm{n}$ & $\%$ & \\
\cline { 2 - 5 } & 16 & 61,5 & 0 & 0 & \\
\hline Tekanan Darah $\leq 120 / 80 \mathrm{mmHg}$ (Tidak Hipertensi) & 0 & 0 & 10 & 38,5 & 0,001 \\
\hline Tekanan Darah $\geq 140 / 90 \mathrm{mmHg}$ (Hipertensi) & 16 & & &
\end{tabular}

Tabel 6 Menunjukkan nilai yang paling tinggi terdapat pada ibu hamil yang memiliki riwayat keturunan dengan hipertensi sebanyak 16 orang $(61,5 \%)$ sedangkan sebanyak 10 orang $(38,5 \%)$ mengatakan tidak ada riwayat keturunan. Pada bagian Pearson Chi-Square terlihat nilai $p=0,001$. Dimana nilai $p=0,001<0,05$, maka ada hubungan antara pemberian kalsium dengan tekanan darah pada ibu hamil dengan hipertensi berdasarkan riwayat keturunan.

\section{PEMBAHASAN}

1. Analisis Univariat

a. Distribusi Frekuensi Pengaruh Pemberian Kalsium Terhadap Tekanan Darah.

Pada penelitian ini hasil analisis menunjukkan bahwa pemberian kalsium berpengaruh terhadap tekanan darah pada ibu hamil dengan hipertensi sebanyak 16 orang $(61,5 \%)$ sedangkan yang tidak berpengaruh sebanyak 10 orang $(38,5 \%)$. Pengaruh pemberian kalsium terhadap tekanan darah pada ibu hamil dengan hipertensi ini berpengaruh jika kadar kalsium total memiliki korelasi yang signifikan dan negative dengan kekuatan hubungan yang cukup pada tekanan darah sisitolik artinya jika kadar kalsium total pada serum darah rendah maka tekanan darah sistolik akan meningkat secara signifikan. (5)

Beberapa peneliti melakukan uji klinis dan melaporkan bahwa berkurangnya kejadian hipertensi hingga pre eklamsi dengan kalsium suplementasi, yang lain melaporkan asosiasi tekanan darah rendah dengan kalsium makanan yang lebih tinggi. Studi epidemiologi telah menungkapkan hubungan terbalik antara asupan kalsium selama hamil dan yang mengalami pre eklamsia. (4)

b. Distribusi Frekuensi Pengaruh Kalsium Terhadap Tekanan Darah Berdasarkan Usia

Sebagian besar sama yaitu responden ibu hamil dengan hipertensi berada pada rentang umur $20-35$ Tahun sebanyak 13 
orang $(50 \%)$, sementara umur $>35$ Tahun sebanyak 13 Orang (50\%), responden termasuk kategori usia yang reproduktif. Umur ibu pada waktu hamil merupakan salah satu faktor yang mempengaruhi kelangsungan kehamilan dan merupakan salah satu faktor terjadinya hipertensi. Dan pada usia tua ( $\geq 35$ Tahun) akan menambah terjadinya komplikasi kehamilan.

Penelitian sebelumnya menunjukkan bahwa dengan bertambahnya umur ibu mengakibatkan absorbsi tubuh cenderung memburuk dan alat reproduksinya sudah mulai degenerasi sehingga kemungkinan terjadinya komplikasi (6)

c. Distribusi Frekuensi Pengaruh Kalsium Terhadap Tekanan Darah Berdasarkan Paritas

Hasil penelitian menunjukkan sebagian responden ibu hamil dengan hipertensi yang memiliki anak lebih dari satu sebanyak 12 orang $(46,2 \%)$ dan yang memiliki lebih dari lima orang anak sebanyak 8 orang $(30,8 \%)$.

Hal ini sesuai dengan teori yang mengatakan bahwa paritas 1 dan paritas tinggi (lebih dari 3) mempunyai angka kematian maternal lebih tinggi. Lebih tinggi paritas, lebih tinggi kematian maternal. Hasil penelitian ini menunjukkan bahwa sebagian besar responden mengalami preeklampsia berat. Kejadian ini harus diatas agar tidak terjadi masalah yang lebih beresiko. (7)

d. Distribusi Frekuensi Pengaruh Kalsium Terhadap Tekanan Darah Berdasarkan Riwayat Keturunan

Menunjukkan reponden ibu hamil dengan hipertensi yang memiliki riwayat keturunan sebanyak 16 orang $(61,5 \%)$, sementara yang tidak memiliki riwayat keturunan sebanyak 10 orang $(38,5 \%)$. Beberapa keluarga memiliki risiko lebih tinggi dibandingkan dengan keluarga lainnya. Misalnya risiko wanita hipertensi untuk menderita hipertensi meningkat jika ayah, ibu atau saudara menderita hipertensi berhubungan dengan mutasi genetik. Hal ini lebih sering ditemukan pada beberapa kelompok etnik dan keluarga. Wanita dengan mutasi genetik memiliki peluang besar $80 \%-90 \%$ untuk menderita hipertensi (8)

2. Analisis Bivariat

a. Pengaruh Pemberian Kalsium Terhadap Tekanan Darah Pada Ibu Hamil Dengan Hipertensi

Berdasarkan tabel 5 menunjukkan bahwa pada masing-masing kelompok terdapat hasil analisis saat penelitian yaitu, pada kelompok pemberian kalsium terhadap tekanan darah yang berpengaruh sebanyak 16 orang $(61,5 \%)$ dan yang tidak berpengaruh sebanyak 10 orang $(38,5 \%)$ dapat dikatakan berpengaruh setelah diberikan susu berkalsium $40 \%$ yang di observasi selama 3 hari. Pemberian kalsium menggunakan susu berkalsium ini dari hasil analisis memiliki nilai $\mathrm{p}=0,001$, dimana $0,001<0,05$, maka ada pengaruh pemberian kalsium terhadap tekanan darah.

Kekurangan kalsium yang terlalu lama menyebabkan dikeluarkannya kalium dari jaringan otot sehingga menimbulkan manifestasi keluar dari otot jantung menimbulkan melemahnya kontraksi otot jantung dan menurunnya volume sekuncup, sehingga aliran darah akan menurun, keluar dari otot pembuluh darah akan menimbulkan kontraksi, vasokontriksi dan meningkatkan tekanan darah tinggi.

Hasil analisis ini sejalan dengan penelitian sebelumnya bahwa berkurangnya kejadian hipertensi hingga preeklamsi dengan kalsium suplementasi, yang lain melaporkan asosiasi tekanan darah rendah dengan kalsium makanan yang lebih tinggi. Studi epidemiologi telah menungkapkan hubungan terbalik antara asupan kalsium selama hamil dan yang mengalami pre eklamsia. (4) juga sesuai dengan penelitiam lainnya yang menunjukkan bahwa ada hubungan antara konsumsi susu dengan hipertensi dalam kehamilan yang dapat menurunkan resiko hipertensi sebesar 2,545 kali. (10)

Dari hasil penelitian ini disimpulkan ada hubungan antara kalsium dan tekanan 
darah karena kalsium dapat mengurangi tekanan darah memainkan peran penting sebagai mediator dalam konstriksi dan relaksasi pembuluh darah, menurut Linus Pauling Institute di Oregon State University. Demikian pula, kalsium sangat penting untuk kontraksi dan relaksasi otot. Mengkonsumsi makanan rendah kalsium menyebabkan penurunan konsentrasi ion kalsium dalam cairan antarsel. Ini mengangkat kedua bentuk aktif dari vitamin D, vitamin D3, dan hormon paratiroid menghasilkan konsentrasi kalsium meningkat dalam sel otot polos. Pergeseran konsentrasi kalsium akan meningkatkan resistensi pembuluh darah, meningkatkan tekanan darah. ${ }^{(5)}$

b. Pengaruh Usia Dengan Pemberian Kalsium Terhadap Tekanan Darah Pada Ibu Hamil Dengan Hipertensi

Tabel 4 menunjukkan jika masingmasing memiliki nilai yang sama yaitu persentasi $50 \%$ pada pengaruh pemberian kalsium pada ibu hamil hipertensi berdasarkan usia. Dan dari keseluruhan hasil analisis nilai $\mathrm{p}=0,023$, artinya jika hasil penelitian ada pengaruh antara pemberian kalsium terhadap tekanan darah ibu hamil dengan hipertensi berdasarkan usia. Penelitian ini menunjukkan bahwa dengan bertambahnya umur ibu mengakibatkan absorbsi tubuh cenderung memburuk dan alat reproduksinya sudah mulai degenerasi sehingga kemungkinan terjadinya komplikasi. (6)

Hasil penelitian ini sejalan dengan beberapa pendapat yang menyatakan bahwa semakin bertambahnya umur semakin bertambah usia dapat menyebabkan tekanan darah meningkat, dengan kata lain usia yang semakin tua memungkinkan seseorang menderita hipertensi juga besar (11) Hasil penelitian sebelumnya membuktikan bahwa umur semakin tua maka risiko terkena penyakit hipertensi juga semakin besar.

Hubungan peningkatan usia maternal terhadap hipertensi kehamilan sama, dan meningkat lagi saat usia diatas 35 tahun.
Hipertensi karena kehamilan paling sering mengenai wanita tua. Telah dilaporkan di RSUP Dr.Kariadi Semarang Tahun 2008, bahwa wanita diatas 35 tahun mengalami hipertensi dalam kehamilan dengan 29 kehamilan mengalami preeklamsia berat, 22 preeklamsia ringan, 3 eklamsia, 7 superimpose preeklamsia, 11 hipertensi gestasional dan 4 hipertensi kronis. (13) Pengaruh Paritas Dengan Pemberian Kalsium Terhadap Tekanan Darah Pada Ibu Hamil Dengan Hipertensi.

Tabel 5 memperoleh analisis sebagian responden ibu hamil dengan hipertensi yang memiliki anak lebih dari satu sebanyak 12 orang $(46,2 \%)$ dan yang memiliki lebih dari lima orang anak sebanyak 8 orang $(30,8 \%)$. Pada bagian Pearson Chi-Square terlihat nilai $p=0,941$. Dimana nilai $p=0,941>0,05$, (Tabel 5) maka tidak ada hubungan antara pemberian kalsium dengan tekanan darah pada ibu hamil dengan hipertensi berdasarkan paritas. Hal ini menunjukkan bahwa hipertensi dalam kehamilan dapat pula terjadi pada ibu primigravida maupun multigravida, ini sepadan dengan penelitian terdahulu, yang menunjukkan hipertensi dalam kehamilan atau preeklampsia banyak juga terjadi pada primigravida.

Hasil penelitian ini sama dengan hasil penelitian yang menunjukkan bahwa dari 30 reponden 20 diantaranya $(66,7 \%)$ memiliki paritas 2-3. Dari hasil pengolahan data diketahui tidak ada hubungan yang bermakna antara paritas dengan konsumsi kalsium maupun kejadian preeklamsia. Hal ini menunjukkan bahwa preeklamsi dapat pula terjadi pada primigravida maupun multigravida, ini sepadan pula dengan penelitian yang menemukan jika angka kejadian preeklamsia juga pada kehamilan primigravida. (12) Pengaruh Riwayat Keturunan Dengan Pemberian Kalsium Terhadap Tekanan Darah Pada Ibu Hamil Dengan Hipertensi

Ibu hamil dengan hipertensi yang memiliki riwayat keturunan sebanyak 16 orang $(61,5 \%)$, sedangkan yang tidak memiliki riwayat keturunan sebanyak 10 orang $(38,5 \%)$. Pearson Chi-Square terlihat 
nilai $p=0,001$. Dimana nilai $p=0,001<0,05$, maka ada hubungan antara pemberian kalsium dengan tekanan darah pada ibu hamil dengan hipertensi berdasarkan riwayat keturunan. (Tabel 6)

Beberapa keluarga memiliki risiko lebih tinggi dibandingkan dengan keluarga lainnya. Misalnya risiko wanita hipertensi untuk menderita hipertensi meningkat jika ayah, ibu atau saudara menderita hipertensi berhubungan dengan mutasi genetik. Hal ini lebih sering ditemukan pada beberapa kelompok etnik dan keluarga.

Dari hasil analisis penelitian ini sama dengan hasil penelitian yang menyatakan bahwa faktor keturunan dengan hipertensi dalam kehamilan sebagian responden yaitu 28 orang $(70 \%)$ yang memiliki fator keturunan. Berdasarkan data tersebut berkaitan dengan teori yang mengatakan bahwa wanita yang beresiko terkena bentukbentuk hipertensi dalam kehamilan antara lain mereka yang memiliki riwayat pribadi atau keluarga yang pernah terkena hipertensi kehamilan. (15)

\section{KESIMPULAN}

Ada pengaruh antara pemberian kalsium terhadap tekanan darah. Ada pengaruh antara pemberian kalsium terhadap tekanan darah berdasarkan usia, riwayat keturunan, dan tidak ada hubungan dengan paritas.

\section{SARAN}

Agar lebih meningkatkan penyuluhan kesehatan bagi Ibu Hamil untuk mengkonsumsi susu berkalsium sejak awal kehamilan untuk menekan terjadinya hipertensi dalam kehamilan, disarankan mengkonsumsi susu berkalsium sejak awal kehamilan selain untuk pertumbuhan tumbuh kembang janin, juga mampu menambah pengetahuan ibu tentang pentingnya mengkonsumsi susu berkalsium setiap hari, selanjutnya diharapkan dapat meneliti dengan sampel yang lebih banyak dan dapat meneliti pengaruh lain dari pemberian kalsium terhadap tekanan darah pada ibu hamil dengan hipertensi.

\section{DAFTAR PUSTAKA}

1. Manuaba C. Ilmu Kebidanan Penyakit Kandungan dan KB. Jakarta: EGC; 2010.

2. Dinas Kesehatan Kalimantan Tengah. Profil Dinas Kesehatan Kalimantan Tengah [Internet]. Dinas Kesehatan Provinsi Kalimantan Tengah. 2017. Available from: http://www.depkes.go.id/resources/download/profil/PROFIL_KES_PROVINSI_2016/21 Kalteng_2016.pdf

3. Mose JC, Anwar AD. Kehamilan Risiko Tinggi: Perkembangan, Implikasi Klinis, \& Kontroversi. Jakarta: Sagung Seto; 2015.

4. Chhabra S, Singh A. Role of Calcium in Hypertensive Disorders of Pregnancy Current Status of Research a Mini Review. J Nutr Disord Ther. 2017;7(2):1-5.

5. Puspita E. Faktor-Faktor Yang Berhubungan Dengan Kepatuhan Penderita Hipertensi Dalam Menjalani Pengobatan (Studi Kasus Di Puskesmas Gunungpati Kota Semarang). Universitas Negeri Semarang; 2016.

6. Sukfitrianty, Aswadi AMHRL. Faktor Risiko Hipertensi Pada Ibu Hamil Di Rumah Sakit Hikmah Kota Makassar. Al-Sihah Public Heal Sci J. 2016;8(1):79-88.

7. Wiknjosastro H. Ilmu Kebidanan. Jakarta: Yayasan Bina Pustaka-Sarwono Prawirohardjo; 2002.

8. Russel DM. Bebas dari 6 Penyakit Paling Mematikan. Yogyakarta: Media Pressindo; 2011.

9. Manuaba C. Gawat Darurat Obstetri Ginekologi Dan Obstetri Ginekologi Social Untuk Profesi Bidan. Jakarta: EGC; 2008.

10. Marfitarini W. Hubungan Pola Konsumsi Sayur, Buah, dan Susu dengan Hipertensi dalam Kehamilan. Universitas Gadjah Mada Yogyakarta; 2009.

11. Khasanah N. Waspadai Beragam Penyakit Degeneratif Akibat Pola Makan. Yogyakarta:

Volume 6 Nomor 1. Juli-Desember 2018 
Laksana; 2008.

12. Sugiharto A, Hadisaputro S, Adi S, Chasani S. Faktor-Faktor Risiko Hipertensi Grade II Pada Masyarakat ( Studi Kasus di Kabupaten Karanganyar ) Risk Factors of Grade II Hypertension in Community ( Case Study at Karanganyar District ). Ratio. 2006;26.

13. A.R D, B.A P. Luaran Maternal Dan Perinatal Pada Wanita Usia Lebih Dari 35 Tahun di RSUP dr. Kariadi, Semarang, Tahun 2008 [Internet]. 2008. Available from: http://eprints.undip.ac.id/4733/

14. Sholihah NR, Nurhidayati E. The Correlation Of Calcium Consumption With Preeclamsia Incidence For Pregnant Women TM III In RSU PKU Muhammadiyah Yogyakarta 2010 [Internet]. STIKes Aisyiyah Yogyakarta. 2010. p. 1-12. Available from: digilib.unisayogya.ac.id/

15. Tiran D. Mengatasi Mual Muntah dan Gangguan Lain Selama Kehamilan. Yogyakarta: Diglossia; 2007. 